\title{
Genetic Resources of Katingan Cattle and Effort to Conserve at the Time in Katingan District, Central Kalimantan
}

\author{
Bambang Ngaji Utomo ${ }^{1 *}$, Ermin Widjaja ${ }^{2}$ \\ ${ }^{1}$ Indonesia Research Center for Veterinary Science, RE. Martadinata 30 Bogor 16114, telephone 0251-8331048, \\ faksimilli 0251-8336425 \\ ${ }^{2}$ Indonesia Center for Agricultural Technologi Assessment and Development, Tentara Pelajar No.10, Bogor \\ 16114, telephone 0251-8351277; faksimilli 0251-8350928 \\ *Corresponding author. Email: bng.utomo2004@gmail.com
}

\begin{abstract}
Katingan cattle in Central Kalimantan is unique and they were kept only by Dayak community. Local people (Dayak) were often mentioned by the name of the local cattle, but some of call it is Itah cattle or Helu cattle (ancient cattle). Portrait information of Katingan Cattle were obtained through interviews with Government officials and Farmers as well as field monitoring. This paper is written to see the current existence of Katingan cattle and Regional Government Policy in their conservation efforts. Katingan cattle several years ago dominated 80-90\% ownership by farmers, especially in Pendahara, Buntut Bali and Tumbang Lahang, because they were able to contribute the second largest income $18-28 \%$ after rubber commodity. The current population of Katingan cattle is not clearly known because it was not data collection of the population dynamics. The existence of Katingan cattle has been naturally preserved because it is related to ritual activities. In-situ conservation efforts have not been carried out by the Regional Government although there are ideal locations for conservation areas such as in Buntut Bali Village, there are remote locations like island that are protected by rivers and suitable for conservation activities. It takes a strong commitment of local Government to realize in-situ conservation. Currently, the local government in term of the Agriculture Services of Lamandau District is conducted ex-situ conservation by raising 1 bull and 6 cows of Katingan. The cattle is develop to be 14 tails and 1 cow was dead. The preservation of Katingan cattle both in-situ and ex-situ requires serious government support (technical, institutional, access to capital) to increase the population and income of farmers. The first step that needs to be taken is the registration of Katingan cattle as a new breed, so that, in the later based on a formal juridical, local governement has an obligation to maintain its sustainability and develop it. It is important to collect data on the dynamics of the Katingan cattle population immediately to determine the status of Katingan cattle.
\end{abstract}

Keywords: Katingan cattle, conservation, genetic resources

\section{INTRODUCTION}

Animal genetic resources are playing a vital role in ensuring food security and maintaining genetic diversity [1]. Central Kalimantan has animal genetic resources of local cattle which the Dayak people call Itah cattle, or sometimes "Helu" cattle (ancient cattle). However, Dayak people themselves often call it local cattle. These local cattle are specially raised by the Dayak people along the watershed (Daerah
Aliran Sungai: DAS), especially in the Katingan watershed, so that they were named as Katingan cattle [2]. The term Katingan cattle was proclaimed to distinguish it from other local cows. The naming of cattle was given according to the location of their habitat as was common with other local cattle [3-5]. According to [6] the specific characteristics of Katingan cattle are mainly in the female cattle, the horns are curved forward, there is a bulge on the head between the two horns, and the color of the cattle's 
hair is varying, but the dominant colors are reddish brown and black.

The existence of cattle that are far away in the deep of Central Kalimantan makes these cattle less attention in development. Local government policy was distributing more cattle from outside (especially Bali Cattle) to help increase the cattle population. Raising of the cattle is limited to certain ethnicities and in certain areas it is feared that cattle will not be able to develop optimally. It is possible that genetic erosion will occur as the incessant entry of other local cattle and the introduction of artificial insemination.

The existence of Katingan Cattle in the future is starting to be threatened. Whereas according to [7], local cattle are the best cattle for local communities because they are able to survive based on natural selection for years in term of adaptation to difficult local environmental conditions [8]. For that reason, it is very necessary to maintain local cattle in an area or country because these animals have adapted well to environmental conditions. Katingan Cattle germplasm has the potential to be assembled into superior cattle breeds. This is in line with the mandate of Law no. 18 of 2009, that efforts to conserve native Indonesian livestock are directed within the framework of developing national superior seedlings as one of the efforts to conserve germplasm, namely preserving the genetic potential of livestock for the purpose of engineering national superior seeds. According to [9], the existence of local livestock in various areas needs to be properly identified and documented adequately [10], so that conservation can be carried out properly. Conservation is all forms of activities that involve good management of genetic resources to meet food and agricultural needs at the current and in the future, by maintaining the genetic diversity their contain [9]. In brief, conservation includes activities of protection, preservation, maintenance, rehabilitation, introduction, preservation, utilization and development [11].

The purpose of this paper is to inform the genetic resources of Katingan cattle and current conservation efforts undertaken by local governments and possible conservation strategies to be pursued.

\section{MATERIALS AND METHODS}

The study was conducted in 3 districts in Katingan Regency, namely Tewah Sanggalang

Tumbang Lahang Village [14]. These alluvial soil types come from new deposits which are layered with irregular organic matter content based on their depth
Garing District (Pendahara Village), Malan Island District (Buntut Bali Village) and Katingan Tengah District (Tumbang Lahang Village). Research activities are focused on the identification of Katingan cattle raising activities, environment, potential supporting resources, problems and development prospects.

Various information was obtained from Katingan cattle of farmers, field officers, officers from the Katingan Regency Agriculture Services and officers from related institutions (UPTD) as respondents in extracting primary information.

The type of research is descriptive, namely through survey activities, the data collected comes from primary and secondary data. Primary data comes from interviews with farmers, service officials, field officers and key informants. Apart from interviews, field visits and observations were made. Meanwhile, secondary data were obtained from related institutions and a literature study was conducted.

The data were analyzed descriptively and discussed in accordance with the research objectives. Related to the strategy of preserving and developing Katingan Cattle germplasm in the future, SWOT analysis (Strengths, Opportunities, Weakness, Threats) was carried out [12]. This analysis was based on logic that maximizes strengths and opportunities, however simultaneously can minimize weakness and threats.

\section{RESULTS AND DISCUSSION}

\subsection{Environmental Description and Land Conditions}

In general, the area of Lamandau District is flat with a slope class $<2 \%$. Altitude is in the range of 0 700 meters above sea level. This makes this region have a regime of hot temperatures (isohyperthermic) and a regime of high humidity (udic). Average air temperature ranges from $30-32^{\circ} \mathrm{C}$ and minimum temperature of $25^{\circ} \mathrm{C}$ with an average annual temperature of $27^{\circ} \mathrm{C}$ [13]. The soil type at the observation location was dominated by the Entisol order with a large group of Tropofluvents and Fluvaquents (1: 250,000 scale land system) and geographically is along the Katingan river route where there is Buntut Bali Village and heading up and are formed in river flow paths. These soils have C-organic values $>0.2 \%$ with a soil $\mathrm{pH}$ of 4.0-4.5 [15]. The results of the soil sample examination have 


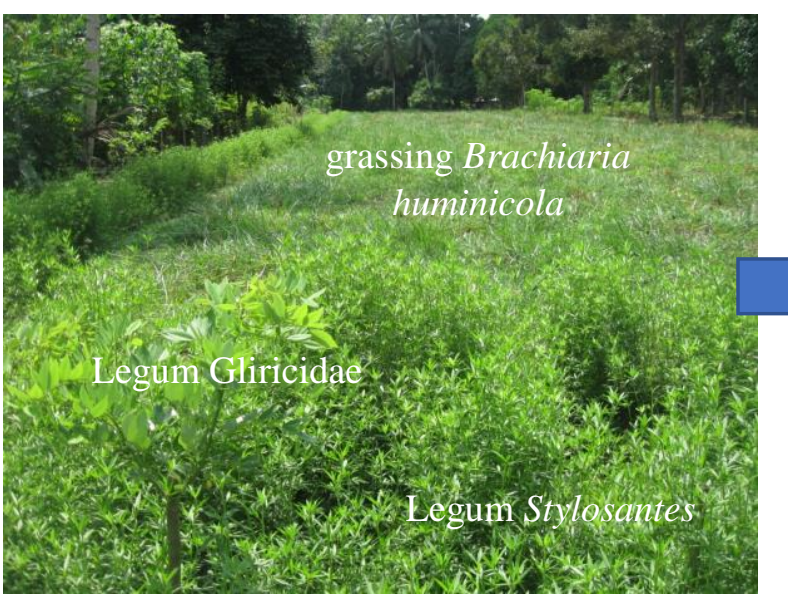

HPT in 3 months old

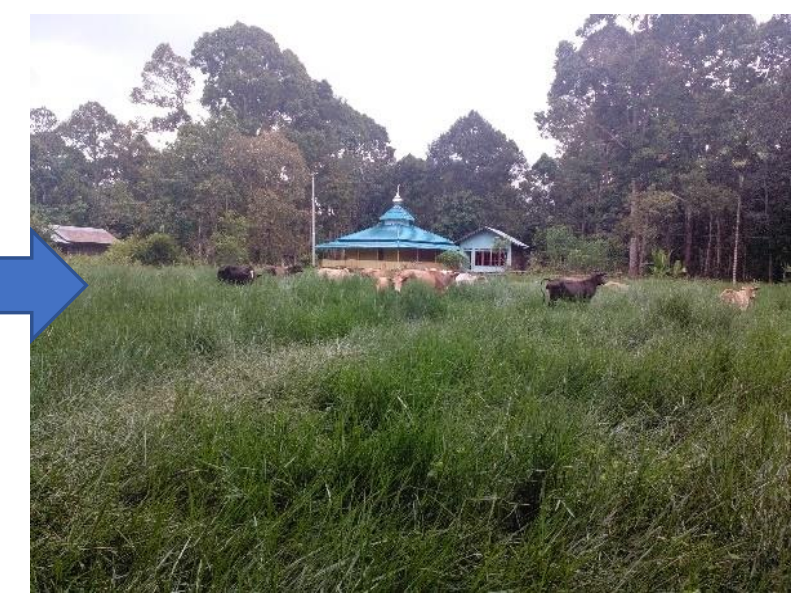

HPT was already grassing

Figure 1. Improvement of the quality of Katingan cattle pasture with the introduction of superior grass and legumes in Katingan District [16].

soil pH: 4.32; N 0.175\%; Organic C 1,695\%; K-dd $0.235 \mathrm{cmol}(+) / \mathrm{kg}$; Na-dd $0.276 \mathrm{cmol} \mathrm{(+)} \mathrm{/} \mathrm{kg;} \mathrm{Ca-}$ dd $0.349 \mathrm{cmol}(+) / \mathrm{kg} ; \mathrm{Mg}-\mathrm{dd} \mathrm{cmol}(+) / \mathrm{kg} ; \mathrm{CEC}$ $14.77 \mathrm{cmol}(+) / \mathrm{kg}$; AL-dd 1,05 cmol (+) / kg; Potential P $2.578 \mathrm{mg} / 100 \mathrm{gr}$; K potential 5,005 mg / 100 gr; Sand $68.89 \%$; clay $20.57 \%$ [2].

The alluvial soils found in the two village areas are generally fertile soils because they contain sufficient nutrients due to river sediment. This allows for agricultural development including animal husbandry through the development of forage areas and pasture areas.

\subsection{Natural vegetation}

The management of the rearing of cattle that is released, relies heavily on feed resources (vegetation) that grow naturally in the pasture. Based on the identification of natural vegetation that grows in the pasture, it consists of several types, namely: Sarang Buaya (Ottochloa nodosa), Teki Grass (Cyperus rotundus), Alang-alang (Imperata cylindrica), Belulang Grass (Eleusine indica), Buffalo Grass (Axonopus compressus), Setaria Grass (Setaria viridis), Malela Grass (Brachiaria mutica), Banta Grass (Leersia hexandra), Jukut pahit, papaitan (Paspalum conjugatum), Knop Grass, Wudelan (Cyperus kyllingia), Kumpai Grass (Hymenachne amplexicaulis), Karamunting (Ochthocharis bornensis), Kalakai (Stenochlaena palustris).

The results of the examination of the nutritional content of pasture vegetation (composite) consisted of $85.05 \%$ dry matter, $7.16 \%$ crude protein, $14.32 \%$ carbohydrates, $1.85 \%$ crude fat, $0.07 \%$ calcium, $0.005 \%$ phosphorus, and energy $102.08 \mathrm{cal} / 100 \mathrm{~g}$.
The protein content is relatively high compared to Imperata $(6.51 \%)$ and rice straw $(5.61 \%)$ [17], also with swamp vegetation $(5.72 \%)$ [18]. Efforts to improve pasture land have been made by [16] through the introduction of superior grass Brachiaria sp and around the edge of the pasture, Stylosantes legumes and Gliricidae trees were developed as legume sources (Figure 1). However, the productivity of forage and livestock itself (Katigan Cattle) has not been reported because research activities are still ongoing. Additional feed (concentrate) is almost never provided, while minerals are sometimes given in the form of table salt.

\subsection{Katingan cattle resources}

The existence of Katingan Cattle has been hundreds of years and has been raised from generation to generation. These cattle can be found along the Katingan watershed, especially in Pendahara Village, Buntut Bali Village and Tumbang Lahang Village (Figure 2). The three locations were the center of Katingan Cattle in Katingan District, Central Kalimantan Province. Rearing management was carried out traditional extensively, released in ranches and in forests with an average ranch area of $<1$ ha and an average cattle ownership of 10-50 tails.

There are 3 models of rearing: (1) cattle were released freely in a ranch that was lined with barbed wire, (2) cattle were released freely in the forest and (3) cattle were released freely but the bridle is tied to a rope stretched between large trees, however, the leash can move so the cattle was only about to roam around the rope being stretched. Daily drinking water was provided on site in buckets or made a pool. 


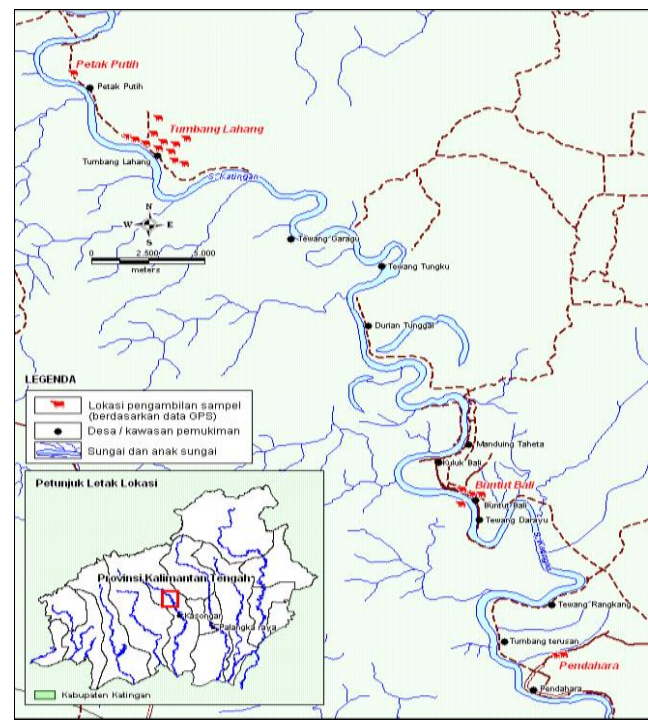

Figure 2. Distribution of Katingan cattle in Katingan District, Central Kalimantan Province

Katingan cattle for local communities provide a very significant income contribution, which was in second position after rubber as the largest contributor to family income (18-28\%) [2]. Apart from being a source of income, Katingan cattle were also maintained for ritual activities. The Dayak people, who are mostly Hindu Kaharingan, prefer the colors of white and red bulls for certain ritual activities. For example, in the Hajat payment program, where to express gratitude for those above the water (Pakanan Umang) using white bulls while those in the water (Pakanan Jata) use red bulls. The same thing related cultural also reported by [19]. At this time, it is relatively difficult to find the white and red bulls of Katingan cattle (Figure 3). This condition has begun to shift given the difficulty of Thus, Katingan cattle have an important role for local communities (Dayak), namely from an economic, cultural and even historical perspective.

Katingan cattle have the potential to be developed because they have adapted to extreme environmental (temperature, humidity, acid land, quality of vegetation), however their reproductive was relatively good. The results of observations in the field found that cows were able to give birth 10-15 times. The size of the cattle is relatively larger than that of Aceh or coastal cattle. Body weight for male cattle was 202.7 - $372.7 \mathrm{~kg}$ while for female cattle was $207.9-255.7 \mathrm{~kg}$ [20].

The population of Katingan cattle is growing slowly and tends to be stagnant. The problems were limited qualitative feed, traditional extensive of rearing management (livestock reproduction was

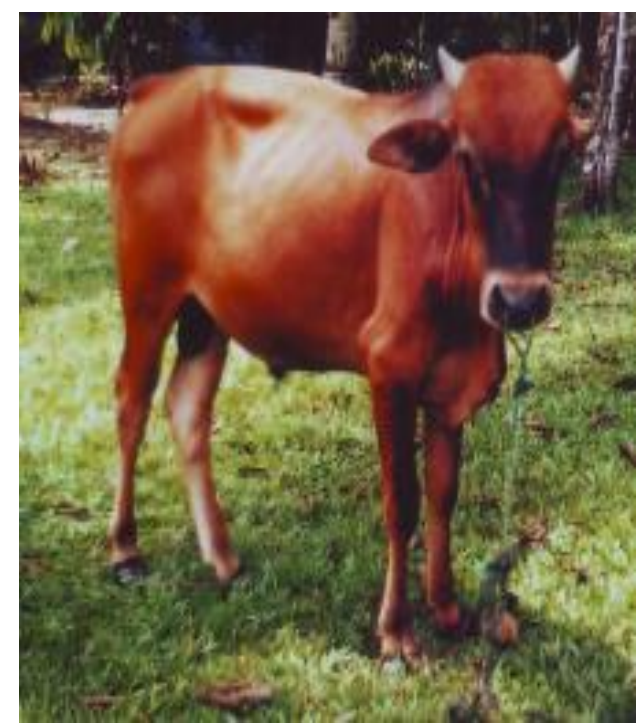

Figure 3. Male Katingan cattle in red

difficult to control), almost no technology introduction, cattle were suffering from $\mathrm{Cu}$ deficiency and it caused late puberty age $>23$ months [21] and frequent cases reproductive disorders in the field such as retention of the placenta and miscarriage. The incessant entry of other local cattle either by local communities themselves or by government programs, it is feared that SDG of Katingan Cattle will gradually experience genetic erosion and even that its existence will be disappear.

Research activities on Katingan cattle are still very limited, so basic information about cattle is also very minimal. [22] even reported no data on Katingan cattle. In fact, this information is very important in relation to the success of the conservationprogram, its utilization and development in the future. However, [2] has carried out several activities as a pilot study on Katingan cattle.

\subsection{Katingan cattle research activities}

Not much research information is available regarding Katingan cattle. Several research activities on Katigan cattle that have been carried out include the morphometric diversity of Katingan Cattle [20], genetic diversity of Katingan Cattle [23], qualitative phenotypic diversity of Katingan Cattle [6], Mating behavior of Katingan Cattle [2], profile of Katingan Cattle farmers [2], puberty of Katingan Cattle [21], mineral status of Katingan Cattle [21] and improvement of feed quality for pasture Katingan Cattle [16]. The population dynamics of Katingan Cattle have never been researched, even though this information is very important to know the status of 
Katingan Cattle itself, whether it is threatened in terms of its population or is it still safe.

Research activities that have been carried out can be a reference for addressing the existence of Katingan Cattle germplasm. There are 2 strategics roles in relation to the research results that have been carried out: (1) improvement of management from Animal Culture (Budaya Peternakan) which was released without any touch of technology to be Animal Husbandry (Budidaya Peternakan), namely improving various aspects of rearing (including the introduction of technology) based on socio-culture and local beliefs. The priority on feed management in order to improve quality as has been done by [16] and mineralization. Several important minerals, mainly related to cattle reproduction, were still below sufficient levels [21], and (2) improving the genetic quality of cattle through selection and conservation. Selection programs can be carried out based on morphometric data, coat color (cultural values) and puberty age. Conservation is carried out in isolated locations so as to minimize other local cattle entering. Thus, it is possible for Katingan cattle to be preserved. One of the locations in Buntut Bali Village is suitable for conservation locations (in-situ conversation). The place is ideal because it is located in the middle of a river like an island and several farmers have made the location a place for raising Katingan Cattle with a free release system. According to [24], conservation of indigenous cattle genetic resources through utilization following pure breeding program and farmer managed in situ approaches may be an appropriate approach for cattle development and rural livelihood enhancement.

\subsection{Current conservation efforts and preservation strategies}

Activities carried out by the Regional Government (Pemda) to conserve Katingan Cattle were purchase 6 cows and 1 male to be kept in a cage owned by the Animal Husbandry Services (nursery). Up to now, it has grown to be 14 tails and 1 dead female parent. Initially maintenance was carried out in the mini ranch but later the maintenance management was housed. Up to now, there is no regional government program that specifically touches Katingan Cattle.

Referring to the current strategic environmental analysis (potential, constraints, opportunities and challenges) in the preservation and development of Katingan cattle, the strategies adopted as presented in Table 1 as follows:

Table 1. Formulation of Katingan cattle conservation and development strategies based on updated information in Katingan District, Central Kalimantan Province.

\begin{tabular}{|c|c|c|}
\hline $\begin{array}{l}\text { INTERNAL } \\
\text { FACTOR }\end{array}$ & $\begin{array}{l}\text { STRENGTH (S) } \\
\text { 1. Availability of land and vegetation } \\
\text { 2. Availability of human resources and interest in } \\
\text { preserving of Katingan cattle } \\
\text { 3. High adaptability of cattle } \\
\text { 4. High ritual value of cattle }\end{array}$ & $\begin{array}{l}\text { WEAKNESS (W) } \\
\text { 1. Limited capital and access } \\
\text { 2. The application of animal } \\
\text { husbandry technology is almost } \\
\text { non-existent } \\
\text { 3. Lack of local government support }\end{array}$ \\
\hline $\begin{array}{l}\text { OPPORTUNITIES }(\mathrm{O}) \\
\text { 1. Government policy in } \\
\text { preserving germplasm } \\
\text { 2. Local market needs for } \\
\text { beef cattle }\end{array}$ & $\begin{array}{l}\text { SO strategy (strategy using strength to take } \\
\text { advantage of opportunities): } \\
\text { 1. Optimizing the use of existing resources } \\
\text { (livestock, land, forages, human resources) to } \\
\text { increase the population and preservation of } \\
\text { Katingan Cattle } \\
\text { 2. Increase the added economic value of Katingan } \\
\text { Cattle through technological innovation and } \\
\text { capital } \\
\text { 3. Establishment of new breeds of Katingan cattle }\end{array}$ & $\begin{array}{l}\text { WO strategy (strategy to overcome } \\
\text { weaknesses by taking advantage of } \\
\text { opportunities): } \\
\text { 1. Increase farmer access to capital } \\
\text { (credit schemes, for example } \\
\text { KUR) } \\
\text { 2. Increasing coaching and } \\
\text { supporting facilitation } \\
\text { 3. Improved maintenance } \\
\text { management }\end{array}$ \\
\hline $\begin{array}{l}\text { THREAT (T) } \\
\text { 1. Local government policy } \\
\text { to enter or distribute other } \\
\text { cattle (Bali Cattle) } \\
\text { 2. Lack of information at the } \\
\text { regional and central levels } \\
\text { about Katingan cattle so } \\
\text { that these cattle are } \\
\text { ignored }\end{array}$ & $\begin{array}{l}\text { ST strategy (strategy using strength to overcome } \\
\text { threats): } \\
\text { 1. Empowerment of Katingan Cattle (by the } \\
\text { Government) to help increase the livestock } \\
\text { population, where the beef cattle program / } \\
\text { policy is more focused on Katingan Cattle } \\
\text { 2. Conducting conservation of Katingan cattle } \\
\text { 3. Disseminating information on the potential for } \\
\text { production, reproduction and genetics of } \\
\text { Katingan Cattle }\end{array}$ & $\begin{array}{l}\text { WT Strategy (Strategy to minimize } \\
\text { weaknesses and overcome threats): } \\
\text { 1. Coaching of cattle raising and } \\
\text { other related aspects for local } \\
\text { farmers } \\
\text { 2. The declaration of the Katingan } \\
\text { Cattle conservation program } \\
\text { 3. Socialization of Katingan Cattle } \\
\text { conservation at the community } \\
\text { level }\end{array}$ \\
\hline
\end{tabular}


Mainly from the strategy adopted in the preservation of Katingan cattle is to increase the role of the Government, in term of policies in empowering Katingan cattle through fostering farmers in farmer groups, development in the form of corporations (Kepmentan 472/2018) and Area-based (Permentan 18/2018) by utilizing potential existing resources so that there is a bargaining position for farmers, capital support for farmers, massive socialization to farmers about the importance of preserving Katingan cattle, introduction of livestock technology, conservation activities and submitting proposals for the establishment of a new breed of Katingan cattle. Technological innovation will not be able to be implemented without the support of capital, for that it needs to be introduced by financial institutions, such as microfinance institutions (LKM) or to be brought closer to credit schemes from the government, for example KUR. The existence of Katingan Cattle must be legalized so that there is attention from policy makers both in the region and at the center, so that Katingan Cattle can later be involved in the development of livestock both regionally and nationally through the determination of a new breed.

\section{CONCLUSIONS}

Katingan cattle can be better developed according to their genetic potential by improving various aspects based on socio-culture and local people's beliefs. Preservation of Katingan Cattle is naturally maintained by existing customs, however based on SWOT analysis, strong local government support and commitment is needed (policy, technical, institutional, access to capital) to increase the population and income of farmers so that the preservation of Katingan cattle can be realized. The establishment of a new breed of Katingan cattle is important to increase the awareness of the regional government and the center in particular in the conservation of Katingan cattle. Improving the quality of cattle is carried out through a better selection and maintenance management program. For this reason, further research activities need to be carried out to enrich data and information. Determination of the in-situ location as a conservation area for the preservation of Katingan cattle and accompaniment related to these activities.

\section{ACKNOWLEDGMENTS}

Thank you to the Head of Agricultural Services of Katingan District, Central Kalimantan, Head of BPP
Pendahara, Buntut Bali and Tumbang Lahang for their support and assistance in the field

\section{REFERENCES}

[1] K. Adebabay, K. Belew, Tesfaye, G. Belay, The State of Conservation of Animal Genetic Resources in Developing Countries: A Review, Int. J. Pharm. Med. Biol. Sci, 5(1) (2016) 58-66

[2] B.N. Utomo, Keragaman fenotipik dan genetik, profil reproduksi serta strategi pelestarian dan pengembangan Sapi Katingan di Kalimantan Tengah. Disertasi. Sekolah Pascasarjanan, Institut Pertanian Bogor, Bogor, 2011. [In Bahasa Indonesia]

[3] M.A.N. Abdullah, Karakterisasi genetik sapi Aceh menggunakan analisis keragaman fenotipk, daerah D-Loop DNA mitokondria dan DNA mikrosatelit. Disertasi. Sekolah Pascasarjana, Institut Pertanian Bogor, Bogor, 2008. [In Bahasa Indonesia]

[4] Sarbaini, Kajian keragaman karakteristik eksternal dan DNA mikrosatelit sapi pesisir Sumatera Barat. Disertasi. Sekolah Pascasarjana, Institut Pertanian Bogor, Bogor, 2004. [In Bahasa Indonesia]

[5] W. Sun, H. Chen, C. Lei, X. Lei, Y. Zhang, Genetic variation in eight Chinese cattle breeds based on the analysis of microsatellite markers. Genet Sel Evol 40 (2008) 681-692.

[6] B.N. Utomo, R.R. Noor, C. Sumantri, I. Supriatna, E.D. Gunardi, B. Tiesnamurti, Keragaman fenotipik kualitatif sapi Katingan, JITV 17(1) (2012) 1-12. [In Bahasa Indonesia]

[7] R.R. Noor, Genetika Ternak, Ed ke-4, Depok: PT. Penebar Swadaya, 2008. [In Bahasa Indonesia]

[8] H. Meydan, Importance of native animal genetic resources, J Genet Mol Biol. 1(1) (2017) 18-19.

[9] Riwantoro, Konservasi plasma nutfah Domba Garut dan strategi pengembangannya secara berkelanjutan [disertasi]. Bogor: Sekolah Pascasarjana, Institut Pertanian Bogor, 2005. [In Bahasa Indonesia]

[10] H. Alebachew, D. Dedecha, Y. Tadesse, Utilization, Collection and Conservation of Animal Genetics Resources in Relation to Indigenous Breeds, World Journal of Food 
Science and Technology 1(1) (2017) 15-21. DOI: $10.11648 /$ j.wjfst.20170101.13

[11] [KNPN] Komisi Nasional Plasma Nutfah, Pedoman Pengelolaan Plasma Nutfah, Deptan. Badan Litbang Pertanian, 2002, p.42. [In Bahasa Indonesia]

[12] Y. Yusdja, N. Ilham N, Arah kebijakan pembangunan peternakan rakyat, Analisis Kebijakan Pertanian 4(1) (2006) 18-38. [In Bahasa Indonesia]

[13] [Puslittanak] Pusat Penelitian Tanah dan Agroklimat, Evaluasi Sumberdaya Lahan untuk mendukung Penataan Ruang di Provinsi Kalimantan Tengah. Laporan Akhir. Bogor: Pusat Penelitian Tanah dan Agroklimat, 1996, 37 halaman. [In Bahasa Indonesia]

[14] A. Bhermana, Peta Sumberdaya Lahan Desa Pendahara, Buntut Bali dan Tumbang Lahang, Kabupaten Katingan Skala 1:250.000, BPTP Kalimantan Tengah, Palangka Raya, 2009. [In Bahasa Indonesia]

[15] S. Hardjowigeno, Ilmu Tanah, PT. MSP, 1987, p.220. [In Bahasa Indonesia]

[16] B.N. Utomo, E. Widjaja, S. Hadiwaluyo, I. Yuanita, Laporan Hasil Kegiatan Peningkatan Produktivitas dan Kesehatan Sapi Lokal Kalimantan Tengah (Sapi Katingan) Melalui Perbaikan Kualitas Hijauan Pakan Ternak pada Manajemen Ranch Ekstensif Tradisional dan Penerapan Sistem Peringatan Dini Penyakit, Balai Besar Penelitian Veteriner, Bogor, 2014. [In Bahasa Indonesia]

[17] B. Agustano, M. Lamid, A. Ma'ruf, M.T.E. Purnama, Identifikasi Limbah Pertanian Dan Perkebunan Sebagai Bahan Pakan Inkonvensional Di Banyuwangi, Jurnal Medik Veteriner 1(1) (2017) 12-22. [In Bahasa Indonesia]
[18] R. Akbar, Liman, A.K. Wijaya, Evaluasi Komposisi Botani dan Nilai Nutrien pada Rumput di Rawa Kecamatan Menggala Kabupaten Tulang Bawang, Jurnal Ilmiah Peternakan Terpadu 5(3) (2017) 72-76.

[19] G.B. Nyamushamba, C. Mapiye, O. Tada, T. E. Halimani, V. Muchenje, Conservation of indigenous cattle genetic resources in Southern Africa's smallholder areas: turning threats into opportunities - A review, Asian-Australas J Anim Sci. 30(5) (2017) 603-621. DOI: 10.5713/ajas.16.0024

[20] B.N. Utomo, R.R. Noor, C. Sumantri, I. Supriatna, E. Gunardi, Keragaman morfometrik sapi Katingan di Kalimantan Tengah, JITV 15(3) (2010) 220-230. [In Bahasa Indonesia]

[21] B.N. Utomo, R.R. Noor, C. Sumantri, I. Supriatna, E.D. Gurnardi, Pubertas Sapi Katingan betina dikaitkan dengan konsentrasi mineral $\mathrm{Cu}$ dan lingkungan, JITV 18(2) (2013) 123-130. [In Bahasa Indonesia]

[22] M. Astuti, A. Agus, S.B.S. Gede, B. Aryadi, L.M. Yusiati, M. Anggriani, Peta Potensi Plasma Nutfah Ternak Nasional, Fakultas Peternakan Universitas Gadjah Mada, Ardana Media dan Rumah Produksi Informatika,Yogyakarta, 2007. [In Bahasa Indonesia]

[23] B.N. Utomo, R.R. Noor, C. Sumantri, I. Supriatna, E. Gurnardi, Keragaman genetik sapi Katingan dan hubungan kekerabatannya dengan beberapa sapi lokal lain menggunakan analisis DNA mikrosatelit, JITV 16(2) (2011) 113-126. [In Bahasa Indonesia]

[24] M.A. Hamid, A. Rahman, M.A. Zaman, K.M. Hossain, Cattle Genetic Resources and their Conservation in Bangladesh, Asian Journal of Animal Sciences 11(2) (2017) 54-64. DOI: 10.3923/ajas.2017.54.64 